\title{
Article \\ Attendance and Perceived Constraints to Attendance at Zoological Gardens during the Spring 2020 COVID-19 Re-Opening: The Czechia Case
}

\author{
Lukáš Nekolný *(i) and Dana Fialová (D)
}

check for updates

Citation: Nekolný, L.; Fialová, D Attendance and Perceived Constraints to Attendance at Zoological Gardens during the Spring 2020 COVID-19 Re-Opening: The Czechia Case. J. Zool. Bot. Gard. 2021, 2, 234-249. https://doi.org/ $10.3390 /$ jzbg2020016

Academic Editor:

Katherine Whitehouse-Tedd

Received: 29 January 2021

Accepted: 5 May 2021

Published: 7 May 2021

Publisher's Note: MDPI stays neutral with regard to jurisdictional claims in published maps and institutional affiliations.

Copyright: (c) 2021 by the authors. Licensee MDPI, Basel, Switzerland. This article is an open access article distributed under the terms and conditions of the Creative Commons Attribution (CC BY) license (https:// creativecommons.org/licenses/by/ $4.0 /)$.
Department of Social Geography and Regional Development, Charles University, 12843 Prague, Czech Republic; dana.fialova@natur.cuni.cz

* Correspondence: lukas.nekolny@natur.cuni.cz

\begin{abstract}
Zoos are one of the most visited tourist and leisure attractions. After all the important Central-European zoos closed in the spring of 2020 due to the COVID-19 pandemic, a few weeks later they started to re-open. The main goal of this article is to evaluate how the number of visits developed after the first zoo re-openings and what specific factors limited attendances the most after the reopening, using the example of Czech zoos in May and June 2020. In addition to the information available on zoos' online communication channels, the authors' questionnaire survey data and attendance data provided by the zoos were used. The results indicate that the attendance was reduced the most by the obligation to buy tickets online, by the closure of state borders, and by a low limit on daily maximum number of visitors allowed. Different approaches to restricting zoos' capacity are discussed and the use of the maximum number of people by surface area of visitor routes at one time to limit attendance is recommended. In the future, this could be a key factor for sustainability of many zoos.
\end{abstract}

Keywords: attendance; zoo; limiting factors; COVID-19; Czechia

\section{Introduction}

The outbreak of COVID-19 caused emergency restrictive measures to be put in place all over the world. All the non-essential activities stopped and, therefore, also the tourist attractions and partly the related infrastructure (accommodation and dining facilities) closed. Museums, galleries, castles, monuments, open-air museums, and botanical and zoological gardens were all closed. However, until this year researchers have not paid attention to the relationship between tourism and the pandemic. Their effects can be shortterm as well as long-term, depending on transport regions and networks [1]. During such crises, tourism is affected selectively, in different magnitudes and on different geographical levels [2]. The economic consequences can be significant and in some cases even fatal-a permanent shutdown [3].

Live nature and animals draw the attention of present society ever more [4]. Generally, we can state that zoos are facilities where live animals are kept and put on display [5,6]. For this reason, they are a significant part of today's tourism and one of the most visited (paid) attractions $[7,8]$ with a more diverse audience than other collection-based institutions. Zoos can be largely perceived not only as tourist attractions but also as leisure destinations [9]. They can be an important part of city landscape design, economic players, symbolic landmarks [10], and informal science institutions, which play a role in education and social and nature interactions [11]. Today, the sense or purpose of zoos is intensively discussed, mainly in a key position of conservation education and animal welfare [12].

Zoos should be focused on the conservation objectives and generate revenue thanks to their great popularity [13-15]. However, zoos differ from other tourist destinations because they have to take care of their animals regardless of whether the facility is open to 
the public or not. Furthermore, zoos by their nature are not profitable establishments but rather institutions that must be subsidized from other sources and activities. Revenue from visitors is fundamental (although in many cases, they do not cover zoos' operation costs).

In Czechia, there is a high number of zoological gardens. Some authors (e.g., [16]) emphasize their importance and high current status in the European context. Because of this and the relatively small area of Czechia in comparison to e.g., Germany or Poland, zoos are often located close to borders. Given the free movement of people between Schengen area states, it can be expected that foreign visitors will play an important role in zoo attendance for these zoos located near the Czech border. Moreover, Prague is one of the most visited European cities [17], which raises the potential of Zoo Praha. The attendance in Czech zoos has been continuously rising and hitting record highs. This reflects zoos' general popularity [15].

Zoos have been a direct consequence of economic, political, environmental and cultural changes [18] and a part of present Western popular culture [19], e.g., location and size are connected to the time of foundation. Nineteenth-century zoos were usually up to 20 ha in extension [20]. Differences must be viewed from the point of view of the history of zoos in a given area. Whereas many zoological gardens in the West were founded already in the 19th century or before World War II (WWII) most of the zoos in post-socialistic countries, including Czechia, were founded after WWII [21]. This resulted in a different location of such facilities within the city and in their different size (zoos founded later are usually larger). Generally, it can be argued that Czech zoos are larger in size than traditional West European zoos. This idea can be important in times of enforced restrictions on capacity.

Surprisingly, zoos had been underestimated in tourism research for a long time [22]. The situation improved in the past two decades, even though the topic of their attendances is not very frequently researched. Attendance is one of the most basic indicators of success. In 2019, an unprecedented number of zoos hit record highs, including the most visited ones, not only in Czechia, but also in Belgium, and the UK [23], leading to the statement "An important aspect in site planning is to coordinate visitor flows in order to avoid excessive congestion that may depreciate visiting experience" ([10], p. 208). This is also crucial in times of anti-epidemic measures.

Fluctuations in the number of visits are natural. An overview of various factors as well as authors dealing with this topic was published, for example, by Su and Lin [24]. The number of visits a zoo receives is influenced by many factors-besides cultural predispositions and the attitude towards keeping of exotic animals by humans it is also affected, for instance, by the size of the population and the gross national income [15]. Year-on-year fluctuations (as well as day-on-day and month-on-month ones) are mainly affected by the weather [25-28]. That is why attendance varies geographically, e.g., zoo attendance in Europe is usually high in the spring. The composition of animals, the desire to differ from other zoos [29], animal star effect (e.g., giant pandas), special events and new exhibits also influence attendance [24]. Some animal houses can even experience a long-term change in their visitor numbers [30]. Methodology (e.g., including paying vs all visitors, annual passes) can also be important [31,32].

Other factors affect the attendance negatively and they do so on various levels—over the long term they include availability, high entrance fees and lack of time [33], whereas over the short term they are, e.g., terrorist attacks [34] and epidemics [24]. Zeng et al. [35] categorized such short-term crises into five categories: human epidemic, animal epidemic, destructive weather conditions and other natural disasters, civil strife and violence, and war or terrorism. Su and Lin [24] highlight the importance of outbreaks of contagious disease that influence travel intentions and attendance of recreational places. They mention mainly the influence of human epidemics, e.g., severe acute respiratory syndrome (SARS) in 2003 in Asia, which had both long- as well as short-term effects on tourism [36]. In the Taipei Zoo the SARS outbreak caused a sharp decrease in numbers of visits [24]. These examples are known especially from Asia. However, in Europe some zoos also had to be temporarily closed due to the incidence of animal diseases e.g., avian flu or foot-and- 
mouth disease. Bratislava Zoo (Slovakia), was closed for several months because of the foot-and-mouth epidemic of 1973 [37]. Similarly, Chester Zoo (UK) was closed to visitors for 41 days during the foot-and-mouth epidemic of 2001. In this case, there was a slight compensatory "bounce-back" for visits missed during the closure [25].

In the spring of 2020, most of Europe's zoos were closed as part of preventive restrictions against COVID-19. It was the first such mass closure of zoos since WWII, when many of them were (partly) destroyed. However, not even then were they closed to such a large extent. "The world has not experienced such a global pandemic before" ([38], p. 2). The pandemic has also meant a completely new situation for zoos, including re-opening with limited services and capacity. This could be one of the key moments in the history of zoos, as it has an impact, among other things, on their economy, and thus on the possibilities of supporting nature conservation.

At the turn of April and May 2020, Czech zoos re-opened but with the restrictive measures arising from the effort to limit undesirable contact among people and to lower the risk of spreading COVID-19 this way. Animal houses and walk-through exhibits stayed closed. Classic restaurants were closed down and food and drinks were sold only for take away. Commentated feeding of animals (e.g., bird shows or training with sea lions), which normally attract a lot of attention, were cancelled temporarily. Online ticket sales were the only available possibility to purchase tickets in all Czech zoos until 24th of May 2020. The restriction of the zoos' and other tourist and leisure-time places' capacity was introduced [39-41]. Re-opening with many limiting measures which can reduce attendance levels were put in place. Figure 1 shows in a timeline the general principles of loosening of COVID-19 constraints as well as a particular Czech development.

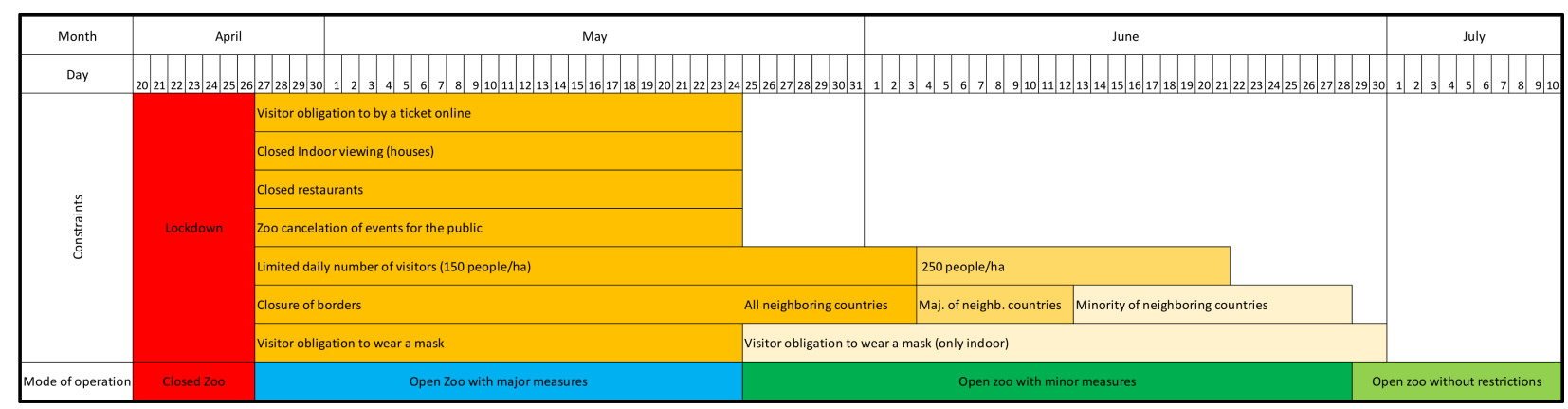

Figure 1. Timeline of the mode of zoo operation and Czech restrictive measures during COVID-19 in spring 2020.

This paper, therefore, seeks to answer questions related to the interest of the public in visiting zoos after their reopening. The aim of the article is to evaluate if the number of visits to Czech zoos in May and June 2020 were significantly different compared to previous years and to evaluate the attendance constraints, mainly the importance of a size and limited capacity approaches. The main questions are "How did the attendance change?", "What specific factors were the most limiting for attendance figures after the reopening?"and "What role is played by size and a limited capacity?".

\section{Materials and Methods}

\subsection{Study Area}

This paper focuses on the country of Czechia, in Central Europe, where the zoological gardens were among the first to start re-opening (from 27 April 2020). In this country, zoos are one of the most visited tourist and leisure places [41]. In spring 2020, there were 29 zoos licensed by the Ministry of the Environment of the Czech Republic [39]. In addition to the 15 traditional zoos founded before 1989, 14 official zoos were established after 1989, but one of them (Terarium Praha) had actually been closed to the public since the spring of 2019. For the sake of comparability, only zoos considered as zoological gardens according to the Nekolný and Fialová [32] typology were included in the research. Thus, indoor exhibitions 
such as aquariums and terrariums with another regime of re-opening were excluded. At the same time, zoos that started to fully operate after 2017 were not included in the study, so that the current data can be compared with the stable average of 2017-2019.

\subsection{Data Collection}

The main aim was to evaluate a possible attendance change and limiting factors, both in the period after the re-opening in spring 2020. Unfortunately, the data availability of both primary objectives of this study was different.

\subsubsection{Attendance Constraints-Website Analysis and Questionnaire}

Questionnaires about perceived factors limiting the zoo attendance were prepared via Google forms and then sent by emails to zoo staff, which have provided authors with attendance data for research purposes. Questionnaire design is described below. Respondents were working mainly in visitor service (or PR) departments, and therefore belong to the best informed section of zoo staff from this point of view. In the emails and the preamble of the questionnaires, it was stated the data would be used for the needs of the research and its publication in a professional journal. Some zoos' representatives excused themselves from completing the questionnaire as they lacked time, information or authorization.

Objective 1 was to analyze and evaluate factors limiting the attendance that emerged as a result of zoos being re-opened in a restricted mode after they had been completely shut in the spring of 2020. Constraints were researched and identified by the author's content analysis of the visit guidelines adopted and presented by the Government of the Czech Republic and the Ministry of Health [39,40] and presented on zoo websites [42-58] and Facebook [59]:

- $\quad$ the closure of borders

- the limited daily number of visitors

- the visitor obligation to buy a ticket online

- the obligation by the zoo to keep the animal houses and walk-through exhibits closed

- the impossibility of the zoo to offer a full gastronomical experience

- the zoo's cancelation of events for the public

- the visitor obligation to wear a mask

Zoos' size was added to discuss the effects of the limited capacity in a broader context. The data on the size are based on the annual report of UCSZOO 2019 [60], additionally on the zoo websites [42-58]. The Czech model of limited capacity was compared to German examples representing zoos of different size (from zoo websites [61-65]).

Following this analysis the questionnaire was created. The zoos were asked to:

- Provide at least an estimate of the share of foreign visits to the zoo last year (Q1)

- Provide the maximum attendance allowed at the zoo based on government restrictions (Q2)

- $\quad$ State from which values of the area size the number of maximum attendance allowed in the zoo was calculated (e.g., total vs. exhibit area) (Q3)

- State whether you consider the given setting of the maximum attendance allowed to be satisfactory? $(\mathrm{Q} 4)$

- State whether you consider the requirement to purchase tickets exclusively online to be justified? (Q5)

By means of an open question the zoos were asked to list the factors they perceived at that moment as limiting their attendance the most: "What factors do you consider to be the most limiting in the time of reduced operation and why?" (Q6). Then the zoos were asked to mark on a scale (1-5) how limiting (or not) in their opinion the above-mentioned factors for each of them were (Q7). The answer "without this limitation" was used when it does not apply to the zoo, e.g., that they have no animal houses or walk-through exhibits. 
Subsequently, all the results were put in an Excel file and descriptive statistics was used and an average of the assessment 1-5 was calculated from these data. In cases of answers "without this limitation" and "I do not know", just the numbers of 1-5 assessments were calculated.

\subsubsection{Attendance Numbers}

Objective 2 was to find out how the attendance in zoos changed during the time when they were re-opened in a restricted mode (May and June 2020) compared with the same time of year in 2017-2019 and to find out the related key factors. The three-year attendance average (2017-2019) was chosen as a compromise considering the possible accessibility and to reduce the effects of weather fluctuations when only comparing data with one year before. The attendance data are based on the annual reports of zoos $[60,66-70]$ and email communications.

Daily figures for 2019 were obtained providing a better and deeper picture in order to evaluate how much the limit on the number of visitors could be reached and could influence the attendance (attendance indicators and number of days over the 2020 limitation in May 2019). Unfortunately, it was not possible to obtain the 2017-2018 data as for other statistics. Not all zoos have this data. May 2019 was affected by adverse weather, which resulted in one of the worst May attendances in recent years. While this may be perceived as limiting, on the other hand, it is a useful comparison of a new specific situation with a situation negatively affected only by the weather.

Descriptive statistics were calculated using Excel (version 2010, Microsoft, Redmond, WA, USA). The correlations (Pearson correlation coefficient) between attendance-indicators were also calculated: the change in May 2020/2017-2019 attendance and the share of foreign visitors (based on Q1); the share of May attendance in the years 2017-19 vs. 2020; the percentage of May in the annual attendance in 2017-19 and the relative attendance change 2020/2017-2019.

We combined the attendance data with the data from annual reports [60,66-70], zoo websites [42-58] and email communications for counting the indicators. These statistical indicators were counted: the limitation coefficient I — an average daily visitation in May 2017-19 (ADV) divided by the limited capacity according to the Government regulations (LDC); and the limitation coefficient II—an average daily visitation on weekends and public holidays (ADWHV) in May 2019 divided by LDC. These numbers show how restricted the limited capacity can be. Further, the visitor load coefficient was calculated as a ratio of ADV to an exhibit size, which presents an average daily number of people per one hectare. This number indicates (at least for guidance) how restricted the size can be.

\section{Results}

Completed questionnaires were obtained from 10 zoological gardens (survey response rate $50 \%$ from 20 invited zoological gardens). If the zoo participated in completing the questionnaire, then it also provided monthly attendance data. The monthly attendance data in 2017-2020 was obtained from 17 zoological gardens and daily attendance data 2019 from 9 of these 17 zoological gardens ([66-70] and email communications).

\subsection{Factors Affecting Attendance after the Re-Opening}

Table 1 shows the basic overview of constraints that can affect attendances after re-opening and their importance as perceived by the zoos (Q7). 
Table 1. Zoo staff responses to a question of the perceived importance of factors limiting zoo attendance, Czechia, spring $2020(N=10)$.

\begin{tabular}{|c|c|c|c|c|c|c|c|c|}
\hline \multirow[b]{2}{*}{ Perceived Factors } & \multicolumn{7}{|c|}{ The Importance of Factors $(\operatorname{Max}=5, \operatorname{Min}=1)$} & \multirow[b]{2}{*}{$\begin{array}{l}\text { Average } \\
\text { Score }\end{array}$} \\
\hline & $\begin{array}{c}5 \\
\text { (Max. Importance) }\end{array}$ & 4 & 3 & 2 & $\begin{array}{c}1 \\
\text { (Min. Importance) }\end{array}$ & $\begin{array}{c}\text { Not } \\
\text { Applicable }\end{array}$ & $\begin{array}{l}\text { "I Do Not } \\
\text { Know" }\end{array}$ & \\
\hline Visitor obligation to buy a ticket online & 5 & 4 & 0 & 0 & 1 & 0 & 0 & 4.2 \\
\hline Obligation by the zoo to keep the indoor & & & & & & & & \\
\hline $\begin{array}{c}\text { viewing (houses) and walk-through } \\
\text { exhibits closed }\end{array}$ & 3 & 3 & 3 & 0 & 0 & 1 & 0 & 4.0 \\
\hline $\begin{array}{l}\text { Impossibility of the zoo to offer a full } \\
\text { gastronomical experience (closed } \\
\text { restaurants) }\end{array}$ & 4 & 3 & 1 & 2 & 0 & 0 & 0 & 3.9 \\
\hline Limited daily number of visitors & 3 & 4 & 0 & 0 & 3 & 0 & 0 & 3.4 \\
\hline Closure of borders & 3 & 2 & 2 & 2 & 1 & 0 & 0 & 3.4 \\
\hline Zoo cancelation of events for the public & 2 & 4 & 1 & 2 & 1 & 0 & 0 & 3.4 \\
\hline Visitor obligation to wear a mask & 0 & 4 & 3 & 1 & 2 & 0 & 0 & 2.9 \\
\hline Size of the zoo & 2 & 2 & 0 & 2 & 3 & 0 & 1 & 2.8 \\
\hline
\end{tabular}

In the questionnaire, Czech zoos considered the requirement to sell tickets only online the most attendance-limiting factor (Table 1). They confirmed it not only in the scale assessment but also in answers to the open question Q6. Online sales were mentioned in $50 \%$ of cases (five out of ten); limited capacity in three cases, the cancelation of activities perceived as not risk ones in general in one case, and the fear of COVID-19 in one case, too. Zoo representatives also expressed the opinion about online sales in communications with the authors in which they apologised for not having completed the questionnaire because they were overloaded with visitors' questions on how to buy the tickets. Moreover, no respondent viewed this measure as justified (on the contrary, e.g., being more medically inadequate because of (longer) manipulation with various forms of online-bought tickets). At the time of the requirement to use only online ticketing processes, most zoos had not yet launched online ticket sales, making it difficult for them to comply with the restriction [42-59]. Most respondents also agreed that such a requirement did not regulate the number of visitors during the day as Czech zoos did not implement a time-slot reservation system.

According to the survey, the fact that schools were closed, could have resulted in parents starting to take their children to zoos as one of the few (first) possibilities to spend free time. Amusement parks and museums only opened later on. That gave zoos an advantage-over a certain period of time there was no other alternative. On the other hand, zoos and other tourist attractions lost visitors from organised school trips and educational programmes. Therefore, as one respondent put in the questionnaire:

"It is not possible to fulfil one of the basic functions of a zoological garden-direct teaching of students. As long as schools are closed, or they operate in a restricted mode, it is not possible (in line with the Ministry of Education guidelines) for students to visit our zoo for educational programmes".

The share of foreign visitors before spring 2020, according to the responses, was very different-with a maximum of more than $40 \%$ in the case of Hodonín and a minimum of only $1 \%$ in the case of Zoo Ústí (Figure 2; Q1). Five out of ten zoos stated at least $20 \%$ of attendance was by foreigners. The closure of borders was not the only restriction of this type though. The Zoo Hluboká re-opened the first six days only for visitors from among the emergency service personnel engaged in fighting COVID-19 [45,59]. During June 2020, bad weather was a deterrent for attendance according to one respondent. 


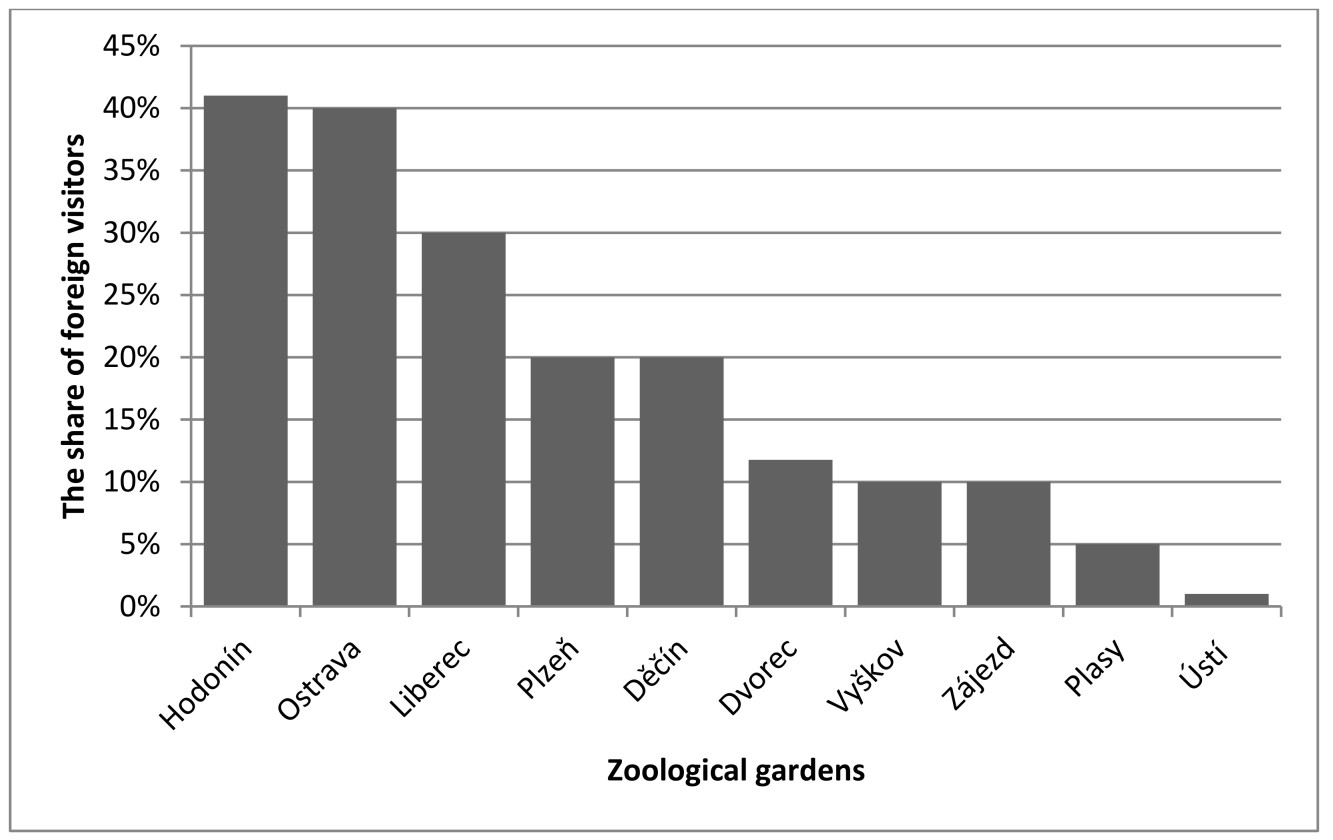

Figure 2. The estimated share of foreign visitors in selected Czech zoological gardens $(N=10)$.

\section{Restriction of the Zoo Capacity}

The capacity limits were established in Czech zoological gardens using the method of maximum number of people by area size per day; in particular, the limit of 150 people per hectare and day (raised to 250 people in June, Figure 1). This way, the most visited Czech zoo, the Zoo Praha, could have on its grounds up to 8500 people per day (Table 2), which corresponds to two thirds of their usual number of visitors during weekends at the same time of year (mentioned on the zoo website [53]). Saturday, 30th of May 2020, was the first weekend in which the obligation to purchase an online ticket no longer applied, but capacity was still limited. At the same time, the Zoo Praha opened a long-announced exhibit. The interest of visitors was so great that the zoo had to close the entrance gates for other visitors at 1 p.m. when its daily limited capacity (DLC) was reached. Although the number of people in the zoo decreased in the afternoon, other visitors could not be admitted [53,59]. In the survey, a limitation based on maximum at one time was mentioned as a fairer concept for smaller zoos.

Table 2 shows the average daily visitation (ADV) in May 2017-2019 divided by the limited daily capacity (LDC) according to the Government regulations-the limitation coefficient I. This would indicate occupancy at average attendance regardless of its uneven distribution during weeks. On weekends, attendance is significantly higher than on weekdays, so the resulting number below one does not mean that the limit is not reached. In three cases of zoos smaller than 10 hectares the limitation coefficient I (ADV/LDC) was over 0.8 , meaning on a very high level. Similarly, the visitor load coefficient (ADV/exhibit size) was over 150, meaning more than three times higher than in case of four zoos with size over 20 hectares (In case of Table 2, not all information was available for all zoos, so only 13 zoos with all of the data were included). Although Zoo Děčin reached a value of only 0.37 for ADV /LDC, at the same time the May 2019 attendance was 7\% over the 2020 limitations (see Table 3). 
Table 2. Figures on the Size and the Facility Capacity of selected Czech Zoos According to the Government Regulations ( $N=13 ;$ sorted by ADV $/$ LDC; ${ }^{*}$ pedestrian + safari parts).

\begin{tabular}{|c|c|c|c|c|c|c|c|}
\hline Zoological Garden & Size (ha) [60] & $\begin{array}{c}\text { Exhibit Size (ha) } \\
\text { [60] (ES) }\end{array}$ & $\begin{array}{l}\text { Size According to } \\
\text { the Limited } \\
\text { Capacity (ha) }\end{array}$ & $\begin{array}{c}\text { Limited Capacity of } \\
\text { Czech Zoos According to } \\
\text { the Government } \\
\text { Regulations (LDC) }\end{array}$ & $\begin{array}{c}\text { Average Daily } \\
\text { Visitation May } \\
\text { 2017-2019 (ADV) }\end{array}$ & $\begin{array}{l}\text { Visitor Load } \\
\text { Coefficient } \\
\text { (ADV/ES) }\end{array}$ & $\begin{array}{l}\text { Limitation } \\
\text { Coefficient I } \\
\text { (ADV/LDC) }\end{array}$ \\
\hline Zoo Ústí & 26 & 25 & 26 & 3900 & 685 & 27.39 & 0.18 \\
\hline Zoo Olomouc & 43 & 23 & 42.5 & 6375 & 1339 & 58.24 & 0.21 \\
\hline Zoo Brno & 41.3 & 25 & 36.67 & 5500 & 1270 & 50.81 & 0.23 \\
\hline Zoo Děčín & 6 & 5 & 6 & 900 & 336 & 67.15 & 0.37 \\
\hline Zoo Vyškov & 9 & $4+4$ & 9 & 1350 & 701 & 87.58 & 0.52 \\
\hline Zoo Liberec & 14 & 12 & 13 & 1950 & 1154 & 96.13 & 0.59 \\
\hline Zoo Plzeň & 47 & 21 & 21 & 2850 & 1752 & 83.43 & 0.61 \\
\hline Zoo Praha & 58 & 50 & 56.7 & 8500 & 5281 & 105.62 & 0.62 \\
\hline Zoo Hodonín & 5.7 & 4.2 & 6 & 900 & 740 & 176.26 & 0.82 \\
\hline Zoo Jihlava & 8.9 & 8.3 & 10 & 1500 & 1347 & 162.29 & 0.90 \\
\hline Zoo Hluboká & 6 & 4.8 & 6 & 900 & 813 & 169.38 & 0.90 \\
\hline
\end{tabular}

Table 3. The Comparison of the Attendance Parameters of Selected Czech Zoos ( $N=9$; sorted by Limitation coefficient II).

\begin{tabular}{|c|c|c|c|c|c|c|c|c|c|c|}
\hline $\begin{array}{l}\text { Zoological } \\
\text { Garden }\end{array}$ & $\begin{array}{l}\text { Exhibit } \\
\text { Size } \\
\text { (ha) }\end{array}$ & $\begin{array}{c}\text { Annual } \\
\text { Attendance } \\
2019[60] \\
\text { /ha/day } \\
\end{array}$ & $\begin{array}{l}\text { Facility } \\
\text { Capacity, } \\
\text { May } 2020 \\
\text { (LDC) }\end{array}$ & $\begin{array}{c}\text { May 2019: Average } \\
\text { Weekend and Public } \\
\text { Holidays Visitation } \\
\text { (ADWHV) }\end{array}$ & $\begin{array}{c}\text { Limitation } \\
\text { Coefficient II } \\
\text { (ADWHV/LDC) }\end{array}$ & $\begin{array}{c}\text { May 2019: } \\
\text { Number of } \\
\text { Days over the } \\
\text { Limitation } 2020\end{array}$ & $\begin{array}{c}\text { May 2019: } \\
\text { Attendance } \\
\text { over the } \\
\text { Limitation } 2020\end{array}$ & $\begin{array}{l}\text { May 2019: Share of } \\
\text { the Attendance over } \\
\text { the Limitation } 2020\end{array}$ & $\begin{array}{l}\text { Est. \% of } \\
\text { Foreign } \\
\text { Visitors }\end{array}$ & $\begin{array}{c}\text { May 2020/19 } \\
\text { Attendance } \\
\text { Change }\end{array}$ \\
\hline Zoo Ústí & 25 & 18 & 3900 & 1028 & 0.26 & 0 & 0 & $0 \%$ & $1 \%$ & $+31.7 \%$ \\
\hline Zoo Ostrava & 60 & 26 & 15,000 & 4563 & 0.30 & 0 & 0 & $0 \%$ & $40 \%$ & $-42.9 \%$ \\
\hline Zoo Dvưr Králové & $53 / 30$ & 49 & 4500 & 2479 & 0.55 & 0 & 0 & $0 \%$ & - & $-46.9 \%$ \\
\hline Zoo Děčín & 5 & 60 & 900 & 663 & 0.74 & 3 & 706 & $7.0 \%$ & $20 \%$ & $-9.8 \%$ \\
\hline Zoo Liberec & 15 & 92 & 1950 & 1481 & 0.76 & 3 & 1573 & $5.3 \%$ & $30 \%$ & $-37.6 \%$ \\
\hline Zoo Vyškov & 8 & 69 & 1350 & 1218 & 0.90 & 6 & 2799 & $14.7 \%$ & $10 \%$ & $-23.6 \%$ \\
\hline Zoo Jihlava & 8.3 & 114 & 1500 & 1812 & 1.21 & 7 & 6264 & $18.4 \%$ & - & $-37.0 \%$ \\
\hline Zoo Hluboká & 4.8 & 160 & 900 & 1254 & 1.39 & 7 & 5163 & $23.1 \%$ & - & $-53.8 \%$ \\
\hline Zoo Hodonín & 4.2 & 127 & 900 & 1385 & 1.54 & 7 & 6558 & $31.6 \%$ & $41 \%$ & $-40.9 \%$ \\
\hline
\end{tabular}


Figures from Czech zoological gardens show that in May 2019 the LDC limit in Jihlava, Hluboká or Hodonín could be exceeded on seven days, while in Ústí or Ostrava on zero days, so the Zoo Ústí theoretically did not lose any visitors due to the limit but the Zoo Hluboká lost over 23\% of visits in May. In 2019 the visit number per hectare per day was very different: 160 visits in Hluboká, whereas in the case of the Zoo Ústí it was only 18 (Table 3). The average visitation on weekends and public holidays (AWHV) in May 2019 was above the LDC in case of Jihlava, Hluboká as well as Hodonín (limitation coefficient II ADWHV /LDC over 1). Moreover, in Liberec this parameter was higher than LDC in 2017 or 2018, too. In Ostrava and Hodonín an estimated share of foreign visitors was about $40 \%$ and in both zoos the May 2020/19 attendance change was on a similar level.

The Czech zoos we approached described the limit as improperly set $(\mathrm{Q} 4, N=10$, unsatisfactory in 70\%). The limit was satisfactory mainly for large zoos as it did not restrict them. On the contrary, smaller zoos saw the limit as generally too low or nonsensically set for the entire day in a way that the time distribution of visitors through the course of the day was not taken into account. Moreover, most zoos used their total area size, not the size of the grounds accessible to visitors (Q3), which limited them even more (Table 2). To compare, in Germany, the approach to limitation was conducted on people per visitor area, and usually at one time (Table 4).

Table 4. Examples of German Zoos that Approached the Limitation of the Number on Visitor Numbers Differently, May 2020 ( ${ }^{*}$ the real state).

\begin{tabular}{|c|c|c|c|c|}
\hline Zoo & $\begin{array}{c}\text { Area Size } \\
\text { (ha) }\end{array}$ & $\begin{array}{c}\text { Limit } 1 \text { Person per } \\
20 \mathrm{~m}^{2} \text { of Visitor } \\
\text { Area }\end{array}$ & $\begin{array}{c}\text { Limit } 1 \text { Person per } \\
10 \mathrm{~m}^{2} \text { of Visitor } \\
\text { Area }\end{array}$ & $\begin{array}{c}\text { Limit } 150 \\
\text { People/ha } \\
\text { (Czech Model) }\end{array}$ \\
\hline Tierpark Bischofswerda & 0.75 & 142 at one time * & 284 at one time & 112 per day \\
\hline Tierpark Bochum & 1.9 & 300 at one time & 600 at one time * & 285 per day \\
\hline Zoo Krefeld & 14 & 650 at one time & 1300 at one time $*$ & 2100 per day \\
\hline Opel-Zoo Kronberg & 27 & 1000 at one time * & 2000 at one time & 4500 per day \\
\hline Tiergarten Nürnberg & 65 & 3250 at one time * & 6500 at one time & 9750 per day \\
\hline
\end{tabular}

\subsection{Attendance: The Demand of Visitors to Visit in the Restricted Mode}

Czech zoos recorded a gradually increasing number of visitors - the first week (end of April/beginning of May 2020) saw a very low attendance that remained below the average in the next weeks. Generally, the demand in bigger zoos picked up by the beginning of the last week of May after the restriction to buy tickets online was lifted and animal houses re-opened-aligning with the attendance factors described by the zoos in the questionnaire as currently the most important. The worst affected were the zoos with a high proportion of foreign visitors (also see Table 3). The correlation between the change in May attendance (2020/average 2017-2019) and the estimate of the share of foreign visitors before 2020 was very strong (0.86). The correlation between the percentage of May on the annual attendance in 2017-2019 and the relative attendance change in May 2020 in analysed zoos was 0.66 (Figure 3). However, there was no real correlation (0.21) without including Zoopark Zájezd with a completely different trend and significantly lower level of attendance than by the majority of other zoos.

In June 2020, most Czech zoos were already back to normal $\pm 11 \%$ (e.g., Děčín, Olomouc, Plzeň, Ústí) compared with the figures from 2017-2019 (Figure 4). In all 17 analysed zoological gardens the attendance was at $62.9 \%(-37.1 \%)$ of the previous three years average in May 2020, at $97.3 \%(-2.7 \%)$ in June 2020, and at $79.8 \%(-20.2 \%)$ for both months together. However, the attendance changes in particular zoos for May and June 2020 altogether fluctuated between $-0.4 \%$ and $-40.5 \%$ (compared with the 2017-2019 average) with one exception. In the small Zoopark Zájezd near Prague with a lower level of attendance, the relative change was completely different from other zoos (highly positive balance during both months). 


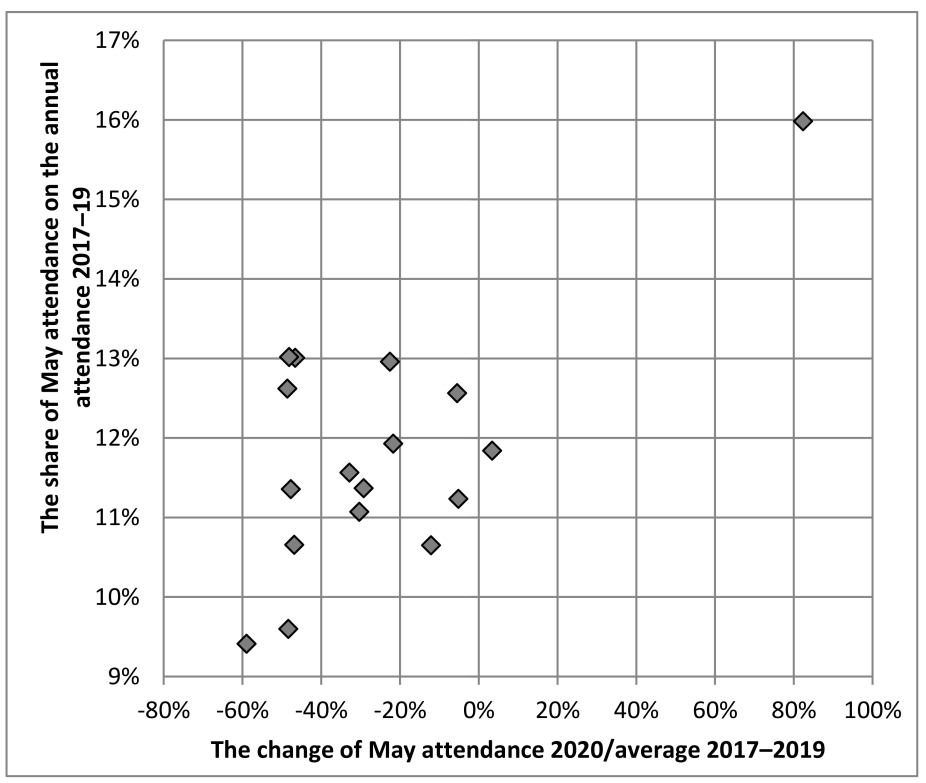

Figure 3. May 2020 Attendance Numbers of Czech Zoos Compared with the 2017-2019 Average in relation to the share on the annual attendance in 2017-2019 $(N=17)$.

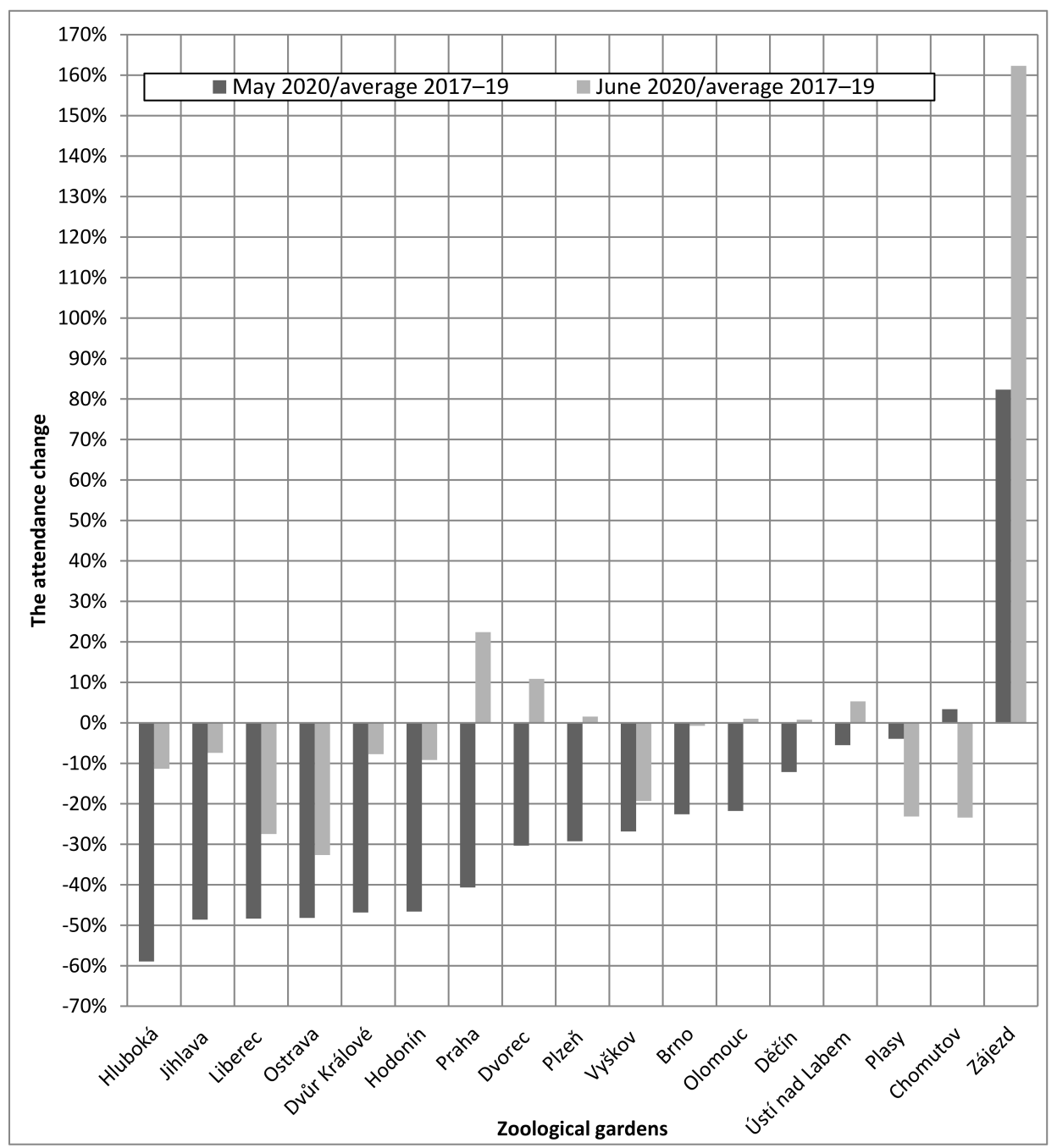

Figure 4. May and June 2020 Attendance Numbers of Czech Zoos Compared with the 2017-2019 Average ( $N=17$; sorted by attendance of May 2020/average 2017-2019). 


\section{Discussion}

COVID-19 fear among the public contributed to lower tourism activity demand [71]. Accordingly, this research confirmed a substantial decrease in zoo attendance after reopening in May 2020 in Czech zoos (Figure 4). Aylen et al. [25] suggest the timing of zoo visits is not random and may be postponed by two weeks, but not for much longer. The analyzed closure of Czech zoos lasted longer (approx. six weeks). However, the situation in 2020 with collective closures was completely new [38]. Moreover, cultural predispositions can also have an impact [15]. The restrictive measures themselves affected zoos differently. Monthly attendance data show that the demand is higher in the spring months, especially in zoos situated in big cities and agglomerations where most of the visitors are locals (e.g., Ostrava). However, it is not possible to say that zoological gardens with a higher share of May attendance numbers in previous years experienced a higher decrease of attendance (Figure 3). Therefore, we can suggest that other factors are important.

\subsection{Limited Capacity and Size}

The imposed limitations for zoos differed with their size (Tables 2-4). Data on size, however, can be misleading because of the different ways in how they are obtained. Sheridan [72] mentions that there may be differences in what is included in the published figures. For example, in the case of a 5-hectare zoo the presence of a hectare body of water, of course, significantly affects the zoo's capacity: but it is still an area accessible for visitors, or rather a visible area. It is unclear whether a particular published figure represents only the area with exhibits accessible to visitors or whether it also represents the car park and the grounds not accessible to visitors or, more precisely, what is an accessible area and what is not. In no way, however, does the total area size represent the usual capacity of a facility.

It follows that the size of a zoo can be considered only an indicative figure rather than a precise parameter that could be easily comparable or that should be used for establishing other indicators, for example the limit on the number of visitors. Moreover, the larger the size, the less dense the routes often are. It is the route system and its length or size that often play a more fundamental role than the size of the facility in terms of the visitor use not only of the zoological gardens, but of gardens and parks in general [73].

Therefore, limits given by the facility size could be prepared in a number of different ways. In Czechia the limit was based on the maximum number of people by area size per day. However, the distribution of visitors in time varies and so does the load on individual zoos based on the size and the length/area of visitor paths. In terms of limiting the contact of people, this Czech restriction does not reflect changes in the number of people in the area during the day or the different density of the path network. As a result, too many visitors can mean a situation where some visitors no longer attend because of their desire to avoid areas of high congestion [74].

The majority of large zoos were assigned a maximum number of people which they would reach only rarely under normal circumstances, anyway, so the limit did not really restrict them (e.g., the Zoo Brno up to 5500 people). By contrast, for mid-sized zoos (approximately 10-20 ha) the limit could be very restrictive because the capacity was set below the usual daily number of visitors (especially on weekends) in the same time of year. For small-sized zoos (up to $10 \mathrm{ha}$ ) where, in addition, the flow of visitors is higher (time needed for the visit is shorter), the limit is very restrictive and, in fact, may mean the maximum capacity was reached very early in the day. In support of this, our findings show that the smaller-sized but frequently visited zoos considered the size a factor that limited the number of visitors the most important. The limit on the number of zoo visitors in Czechia was regularly reached during weekends at small-sized zoos, where the limited daily capacity had a noteworthy impact on attendances. Using the attendance in May 2020 , it is apparent that zoos with a higher probability of exceeding the limit (high level of ADV/LDC; Tables 2 and 3) did lose more visitors. The limit on the number of visitors was increased with effect from June 4 (it was no longer that restrictive even for small-sized zoos) and on 22 June 2020, it was lifted completely (Figure 1). 
In Germany the selected approach was different: most often, the benchmark used was the number of people per size of the grounds accessible to visitors not per the entire day but at any given moment [61-65]. This approach better represents the visitor capacity of a facility. On the other hand, data on the size of the visitor grounds are usually not made public and the zoo has to calculate or estimate them. The Czech model (150 people/ha) was very limiting and inequitable mainly for small-sized zoos. The German model was more restrictive for mid-sized and large zoos (Table 4), but in this case new visitors could enter the zoo during the day after the earlier visitors had left.

\subsection{Other Zoo Attendance Factors}

Implementing an online ticket sale, which was the only possibility to sell tickets in all Czech zoos until 24 May 2020, also posed a limitation. The tickets had to be bought for a specific day, preventing spontaneous visits. In such cases, ticket offices had to stay closed. Until that moment, most zoos had not yet launched online ticket sales, making it difficult for them to comply with the restriction [42-59]. For some visitors internet access could be problematic and those who do not have a smartphone, also needed to print a ticket. On the other hand, the anti-coronavirus measures helped to very quickly implement some new elements of visitor management into practise, especially in connection with the online environment (e.g., online ticket sales or capacity displays on websites).

Zoos re-opened but not all exhibits and services were made accessible. Generally, all animal houses stayed closed. For instance, biotope tropical halls, which are very attractive exhibits, could not be visited. In addition, animal houses give visitors shelter from rain, an advantage that zoos could not offer in the provisional period. Similarly, walk-through exhibits, which are also attractive for visitors, stayed closed. For this reason, Czech zoos could see the closure of animal houses and selected exhibits as one of the most important limiting factors that could discourage people from visiting.

Indoor and terrace restaurants were closed down and food and drinks were sold only for take away. That was the case for zoos too, having an impact on their revenues. As the measures were being relaxed, terraces gradually started to fill up again and, later on, the insides of restaurants too. The limitation of the food and drink on offer was considered in the Czech zoos one of the factors most limiting the number of visitors.

Commentated feeding of animals (e.g., bird shows or training with sea lions), which normally attract a lot of attention, were cancelled temporarily. Special events for lots of people to boost the attendance used to be previously held at the weekends. These were also cancelled in the time of emergency measures with no possibility to make up for them, which can have further negative effects on the attendance in the long term. Numbers below normal were recorded at the Zoo Plasy, a private small-sized zoo that explained the drop in June by a change in the leisure-time opportunities. In May 2020, zoos were practically the only open facilities but in June museums, castles and swimming pools re-opened too. In addition, students went back to school (which was not compulsory), so zoos lost a proportion of children who could visit in May, although not on school trips. There were no school trips in June either even though schools were open again. Such a loss poses a bigger problem for zoos with an overall lower attendance than for zoos with a wider array of visitors.

The situation was not only influenced by the direct measures adopted but also by the long-term visitor structure that converts some zoos into a tourist site and others rather into a free-time destination for locals. It is the latter group in combination with a location in the city that, according to the obtained data, makes for the least impacted zoos. The impossibility for a proportion of potential visitors to visit some zoos became another entirely fundamental parameter. The main reason was the closure of borders. The results indicate a higher decrease of attendance in zoos with a higher share of foreigners on visitor numbers. In many zoological gardens, foreigners represented several tens of percent of visitors in the time before the closure of borders (Figure 2). This confirms that zoos are important tourist attractions, not just local leisure attractions. The specificity and 
uniqueness of a particular zoo can play a key role, e.g., in the Erlebnis-Zoo Hannover, $60 \%$ of visitors are people living outside the city, and $87 \%$ of them have chosen the zoo as their only destination in Hanover [75]. This indicates the necessity for deeper knowledge about the (not only) foreign/nonlocal visitors. The very positive attendance change in Zoopark Zájezd was probably the result of an advertising campaign. This small zoo could be an alternative to the large-sized Zoo Praha for some people.

Furthermore, many European zoos experienced record high attendance numbers in 2019 , as they did also in previous years $(2016,2018)$ [23]. For that reason, when we assess how the crisis affected numbers of visits, we should not forget that we are comparing numbers influenced by COVID-19 with one of the highest numbers ever. On the other hand, May 2019 attendance was one of the worst in the last decade, because of bad weather conditions. Nevertheless, attendance in May 2020 was still much lower. In general, the growing demand for zoos in the past years also led to an assumption that the attendance would continue to grow and that there would be a postponed consumption.

Since 15 June 2020, all the borders with neighboring countries (with one small exception) have been opened for tourism. In the second half of June 2020, therefore, the last real direct restriction was to wear a mask indoors-which the zoos, however, did not see as a very limiting factor for attendance. On the other hand, the school groups were still missing. The biggest driving force for the attendance could be again the weather, which is generally the most significant factor affecting fluctuations in the number of visits [25-27]. Possible lower numbers in June 2020 can be explained by the weather-June 2020 was overall the rainiest in the last 60 years [76] and the possible decrease corresponded to one rainy vs sunny weekend, which research data confirms. Despite this and under the current conditions, no zoo recorded numbers of visits below two thirds of the May + June 2017-2019 average.

For the whole of May 2020 the Zoo Praha reached approximately half the number of visits compared with the figures for the same time in previous years (the lowest May attendance in the past 15 years) [69]. This drop can be largely explained by the closure of borders and the absence of foreigners in Prague, which is otherwise a very popular destination among tourists. At the end of May 2020, the situation changed. The alleviation of the measures together with the opening of the new long-awaited exhibit of Australian fauna called Darwin Crater (both at the end of May 2020), attractive baby elephants and the symbolic entrance fee of 1 CZK for members of the emergency services (during all June 2020) led to an unusually high attendance in June despite rain and even the borders being closed until mid-June. This way, for the first time in at least seven years, the threshold of 13,000 visitors on one day was exceeded in this month. The all-June 2020 attendance hit a record high and it became the month with the most visits apart from July and August in the last 30 years.

In spring 2020, the situation developed and changed every week depending on the measures currently in force (Figure 1). The measures did not only concern zoos, and at the same time the number of active cases of COVID-19 was been decreasing. Fear of illness could also be reduced. When a new awaited exhibit opened, local visitors largely made up for foreigners (e.g., Prague). There was also a partial substitutional effect for school trips where children are also educated about conservation topics. In the future, we could not expect similar development of demand after zoo re-openings as in 2020, e.g., because of an unprecedentedly (more months) long closure of zoos in 2021. Therefore, the need to be prepared on a higher demand of a "bounce-back" is crucial.

A certain limitation of this research is, of course, that the factors putting off visitors were assessed by the zoos, not the visitors. On the other hand, the zoo staff, thanks to the nature of their job and related experience, can estimate visitors' behavior. Only the first months after the zoos re-opened have been taken into account so far. In the long-term perspective the summer months, which make up the lion's share of the annual attendance, are going to be fundamental. It would be convenient, therefore, to continue the research assessing the impacts on the whole season or to create a more in-depth analysis and 
comparison with the situation in other countries where emergency measures had been in force for a different length of time.

\section{Conclusions}

Zoo attendance numbers can be influenced by many factors, including those arising from the effort to lower the risk of spreading a virus such as COVID-19. The results presented in this paper suggest that Czech zoos had significantly lower attendance after re-opening than was usual in previous years. The research data (attendance numbers and respondent feedback) showed that generally the most limiting factors in Czech zoos perceived to be the requirement to buy tickets online (making spontaneous visits impossible and raising a question of how to buy the ticket, eventual people's access to the internet) together with a limited capacity. The worst affected were the zoos with a high proportion of foreign visitors. In the long-term view, for such zoos their loss presents a really big problem, with a need to find new potential visitors in other local regions. Having to close down as well as to operate under restrictions in the spring is evidently a significant economic issue, which can affect the future of zoos and their key functions, including conservation and education. Lower attendance means lower incomes and can lead to the suspension of development and reduced support for conservations projects.

Zoos need to be prepared for another crisis with a clear visitor management plan including marketing. It is crucial to set up a meaningful system to allow as many visitors as possible while meeting any imposed limits. Zoos should be able to actively design such system and do so proactively rather than reactively in response to state-imposed regulation. The need to regulate number of visits may come again at any time. Therefore, we highly encourage calculating the visitor-path area in zoos and initiating the system of limited capacity in such cases based on people per visitor-path area at any one time during the whole day. This model creates opportunity to control the number of people on site over the course of the day, therefore maximizing site capacity more efficiently. For the distribution of attendance during the day, the exclusive online sale of tickets can be implemented, but only in combination with a time-slot reservation system. This model creates the maximum capacity for the whole day, but the flow of people is divided throughout the whole day.

Author Contributions: Conceptualization, L.N.; methodology, L.N.; formal analysis, L.N.; investigation, L.N.; resources, L.N.; data curation, L.N.; writing-original draft preparation, L.N.; writingreview and editing, L.N.; visualization, L.N.; supervision, D.F.; funding acquisition, L.N. All authors have read and agreed to the published version of the manuscript.

Funding: This research was funded by Charles University, grant number SVV260566.

Institutional Review Board Statement: Not applicable.

Informed Consent Statement: Informed consent was obtained from all subjects involved in the study.

Data Availability Statement: Restrictions apply to the availability some of these data. Data was obtained from mentioned zoological gardens and are available from the corresponding author with the permission of particular zoological gardens.

Acknowledgments: We could like to thank Michael Grayson for proofreading the manuscript and providing recommendations for improvements.

Conflicts of Interest: The authors declare no conflict of interest.

\section{References}

1. Hall, M.C.; Scott, D.; Gössling, S. Pandemics, transformations and tourism: Be careful what you wish for. Tour. Geogr. 2020, 22, 577-598. [CrossRef]

2. Page, S.; Yeoman, I.; Munro, C.; Connell, J.; Walker, L. A case study of best practice-Visit Scotland's prepared response to an influenza pandemic. Tour. Manag. 2006, 27, 361-393. [CrossRef]

3. BBC News. Coronavirus: Living Coasts Zoo to Close due to Lockdown. Available online: https://www.bbc.com/news/ukengland-devon-53052526 (accessed on 15 June 2020). 
4. Higginbottom, K. (Ed.) Wildlife Tourism: Impacts, Management and Planning; Common Ground Pty Ltd.: Altona, Australia, 2004.

5. Milstein, T. "Somethin' Tells Me It's All Happening at the Zoo": Discourse, Power, and Conservationism. Environ. Commun. 2009, 3, 25-48. [CrossRef]

6. Habel, A.; Mroczkowski, S. Cele i zadania ogrodów zoologicznych = The objectives and tasks of zoos. J. Educ. Health Sport 2015, 5, 521-528.

7. Woods, B. Good zoo/bad zoo: Visitor experiences in captive setting. Anthrozoös 2002, 15, 343-360. [CrossRef]

8. Baratay, E.; Hardouin-Fugier, E. ZOO: A History of Zoological Gardens in the West; Reaktion Books: London, UK, 2004.

9. Turley, S.K. Conservation and Tourism in the Traditional UK Zoo. J. Tour. Stud. 1999, 10, 2-13.

10. Xu, H.; Li, Q.; Chen, X.; Chen, J.; Guo, J.; Wang, Y. Logistical routing of park tours with waiting times: Case of Beijing Zoo. Tour. Geogr. 2015, 17, 208-222. [CrossRef]

11. Patrick, P.G. Visitors and alignment: Actor-Network Theory and the ontology of informal science institutions. Mus. Manag. Curatorship 2017, 32, 176-195. [CrossRef]

12. Patrick, P.G.; Caplow, S. Identifying the foci of mission statements of the zoo and aquarium community. Mus. Manag. Curatorship 2018, 33, 120-135. [CrossRef]

13. Whitworth, A.W. An Investigation into the Determining Factors of Zoo Visitor Attendances in UK Zoos. PLoS ONE 2012, 7, e29839. [CrossRef]

14. Hosey, G.R.; Melfi, V.; Pankhurst, S. Zoo Animals: Behaviour, Management, and Welfare, 2nd ed.; Oxford University Press: New York, NY, USA, 2013.

15. Davey, G. An analysis of country, socio-economic and time factors on worldwide zoo attendance during a 40 year period. Int. Zoo Yearb. 2007, 41, 217-225. [CrossRef]

16. Van Vliet, E. Zooing the World; Schüling, K. (Verlag): Münster, Germany, 2020.

17. Diskin, G.; Prague's Tourism-A Double-Edged Sword. Tourism Review News 2020. Available online: https://www.tourismreview.com/prague-tourist-hotspot-news11603 (accessed on 20 December 2020).

18. Frost, W. Zoos and Tourism: Conservation, Education, Entertainment?; Channel View Publications, Aspects of Tourism: Bristol, UK, 2011.

19. Anderson, K. Culture and Nature at the Adelaide Zoo: At the Frontiers of 'Human' Geography. Trans. Inst. Br. Geogr. 1995, 20, 275-294. [CrossRef]

20. Van Reybrouck, D. Archaeology and urbanism: Railway stations and zoological gardens in the 19th-century cityscape. Public Archaeol. 2005, 4, 225-241. [CrossRef]

21. Meuser, N. Zoo Buildings: Construction and Design Manual; DOM Publishers: Berlin, Germany, 2019.

22. Mason, P. Zoo Tourism: The Need for More Research. J. Sustain. Tour. 2000, 8, 333-339. [CrossRef]

23. Nekolný, L. High-level attendances at European Zoos in 2019. Zoo Grapevine Int. Zoo News 2020, 2020, $10-11$.

24. Su, A.; Lin, Y. Factors affecting yearly and monthly visits to Taipei Zoo. Theor. Appl. Climatol. 2019, 135, 463-472. [CrossRef]

25. Aylen, J.; Albertson, K.; Cavan, G. The impact of weather and climate on tourism demand: The case of Chester Zoo. Clim. Chang. 2014, 127, 183-197. [CrossRef]

26. Hewer, M.J.; Gough, W.A. Weather sensitivity for zoo visitation in Toronto, Canada: A quantitative analysis of historical data. Int. J. Biometeorol. 2016, 60, 1645-1660. [CrossRef]

27. Perkins, D.R. Using synoptic weather types to predict visitor attendance at Atlanta and Indianapolis zoological parks. Int. J. Biometeorol. 2018, 62, 127-137. [CrossRef]

28. Perkins, D.R.; Debbage, K.G. Weather and Tourism: Thermal Comfort and Zoological Park Visitor Attendance. Atmosphere 2016, 7, 44. [CrossRef]

29. Mooney, A.; Conde, D.A.; Healy, K.; Buckley, Y.M. A system wide approach to managing zoo collections for visitor attendance and in-situ conservation. Nat. Commun. 2020, 11, 1-8. [CrossRef] [PubMed]

30. Nekolný, L. Vývoj návštěvnosti zoologických zahrad Česka, Slovenska a Německa po roce 1989 [Development in attendance rates at zoological gardens in Czechia, Slovakia and Germany after 1989]. Gazella 2018, 43, 190-215.

31. Smith, L. Visitors or Visits? An Examination of Zoo Visitor Numbers Using the Case Study of Australia. Zoo Biol. 2013, 32, 37-44. [CrossRef] [PubMed]

32. Nekolný, L.; Fialová, D. Zoo Tourism: What Actually Is a Zoo? Czech J. Tour. 2018, 7, 153-166. [CrossRef]

33. Nowacki, M. Constrains to Attendance at Visitor Attractions: The Case of Museums, Zoos and Botanic Gardens. Tourism 2015, 25, 29-37. [CrossRef]

34. Richardson, H.W.; Gordon, P.; Moore, J.E., II; Kim, S.; Park, J.; Pan, Q. Tourism and terrorism: The national and interregional economic impacts of attacks on major US theme parks. In The Economic Costs and Consequences of Terrorism; Richardson, H.W., Gordon, P., Moore, J.E., Eds.; Edward Elgar: Cheltenham, UK, 2005; pp. 235-253.

35. Zeng, B.; Carter, R.W.; De Lacy, T. Short-term Perturbations and Tourism Effects: The Case of SARS in China. Curr. Issues Tour. 2005, 8, 306-322. [CrossRef]

36. McAleer, M.; Huang, B.-W.; Kuo, H.-I.; Chen, C.-C.; Chang, C.-L. An econometric analysis of SARS and Avian Flu on international tourist arrivals to Asia. Environ. Model. Softw. 2010, 25, 100-106. [CrossRef]

37. Výročná Správa [Annual Report] Zoo Bratislava 1973; Zoo Bratislava: Bratislava, Slovakia, 1974. 
38. Karabulut, G.; Bilgin, M.H.; Demir, E.; Doker, A.C. How pandemics affect tourism: International evidence. Ann. Tour. Res. 2020, 84, 102991. [CrossRef]

39. Government of the Czech Republic. Measures Adopted by the Czech Government against the Coronavirus. Available online: https:/ / www.vlada.cz/en/media-centrum/aktualne/measures-adopted-by-the-czech-government-against-coronavirus180545/\#general (accessed on 2 July 2020).

40. Ministry of Health of the Czech Republic. Mimořádné opatření-Omezení provozoven a provozů služeb s účinností od 4. do 8. 6 . 2020 [Extraordinary Measure-Restriction of Establishments and Service Operations with Effect from 4 to 8 June 2020]. Available online: https:/ / www.mzcr.cz/dokumenty / mimoradne-opatreni-omezeni-provozoven-a-provozu-sluzeb-s-ucinnosti-od-4do8-_19325_4135_1.html (accessed on 2 June 2020).

41. Czech Tourism. Návštěvnost turistických cílů [The Attendance of Tourist Attractions]. Available online: https://tourdata.cz/ stitek/navstevnost-turistickych-cilu/ (accessed on 2 July 2020).

42. Zoo Brno. Available online: https:/ / www.zoobrno.cz/ (accessed on 10 May 2020).

43. Zoo Děčín. Available online: https:/ / www.zoodecin.cz/ (accessed on 10 May 2020).

44. Zoo Dvůr Králové. Available online: https:/ / safaripark.cz/ (accessed on 10 May 2020).

45. Zoo Hluboká. Available online: https: / / www.zoohluboka.cz/ (accessed on 10 May 2020).

46. Zoo Hodonín. Available online: https:/ / www.zoo-hodonin.cz/ (accessed on 10 May 2020).

47. Zoopark Chomutov. Available online: https:/ / zoopark.cz/ (accessed on 10 May 2020).

48. Zoo Jihlava. Available online: https:/ / zoojihlava.cz/ (accessed on 10 May 2020).

49. Zoo Liberec. Available online: https://www.zooliberec.cz/ (accessed on 10 May 2020).

50. Zoo Olomouc. Available online: https:/ / www.zoo-olomouc.cz/ (accessed on 10 May 2020).

51. Zoo Ostrava. Available online: https:/ / www.zoo-ostrava.cz/ (accessed on 10 May 2020).

52. Zoo Plzeň. Available online: https:/ / www.zooplzen.cz/ (accessed on 10 May 2020).

53. Zoo Praha. Available online: https: / / www.zoopraha.cz/ (accessed on 30 June 2020).

54. Zoo Ústí nad Labem. Available online: https:/ / www.zoousti.cz/ (accessed on 10 May 2020).

55. Zoo Vyškov. Available online: https:/ / www.zoo-vyskov.cz/ (accessed on 10 May 2020).

56. Zoo Dvorec. Available online: https:/ / www.zoodvorec.cz/ (accessed on 10 May 2020).

57. Zoo Plasy. Available online: https:/ / www.zooplasy.cz/ (accessed on 10 May 2020).

58. Zoopark Zájezd. Available online: http:/ / zoopark-zajezd.cz/ (accessed on 10 May 2020).

59. Facebook. Available online: https://facebook.com (accessed on 10 May 2020).

60. Union of Czech and Slovak Zoological gardens. The Annual Report 2019. Available online: http://www.zoo.cz/media/files/07 -30-20-03-15-06vyrocni-zprava-ucszoo-za-rok-2019.pdf (accessed on 10 September 2020).

61. Tierpark Bischofswerda. Available online: https://tierpark-bischofswerda.de/ (accessed on 10 May 2020).

62. Tierpark Bochum. Available online: https://www.tierpark-bochum.de/ (accessed on 10 May 2020).

63. Zoo Krefeld. Available online: https:/ / www.zookrefeld.de/hinweis/ (accessed on 10 May 2020).

64. Opel-Zoo Kronberg. Available online: https://www.opel-zoo.de/ (accessed on 10 May 2020).

65. Tiergarten Nürnberg. Available online: https://tiergarten.nuernberg.de/ (accessed on 10 May 2020).

66. Zoo Olomouc. Výroční zprávy [Annual Reports]. Available online: https://www.zoo-olomouc.cz/vyrocni-zpravy (accessed on 10 September 2020).

67. Zoo Ostrava. Výroční zpráva [Annual Report]. Available online: https://www.zoo-ostrava.cz/cz/zoo/vyrocni-zprava/ (accessed on 10 September 2020).

68. Zoo Plzeň. Výroční zprávy [Annual Reports]. Available online: https://www.zooplzen.cz/o-nas/ke-stazeni/vyrocni-zpravy/ vyrocni-zpravy.aspx (accessed on 10 September 2020).

69. Zoo Praha. Výroční zprávy [Annual Reports]. Available online: https://www.zoopraha.cz/vse-o-zoo/vyrocni-zpravy (accessed on 10 September 2020).

70. Zoo Vyškov. Výroční zprávy [Annual Reports]. Available online: https://www.zoo-vyskov.cz/vyrocni-zpravy (accessed on 10 September 2020).

71. Bakar, N.A.; Rosbi, S. Effect of coronavirus disease (COVID-19) to tourism industry. Int. J. Adv. Eng. Res. Sci. 2020, 7, 189-193. [CrossRef]

72. Sheridan, A. Zooming in on Europe's Zoos: Sheridans Guide to Europe's Zoos 2010-2025; Schüling, K. (Verlag): Münster, Germany, 2016.

73. Van Vliet, E. Orientierungssysteme in Zoos [Orientation systems in zoos]. Tiergarten 2015, 5, 74-76.

74. Fialová, D.; Nekolný, L. Rub a líc turistické přitažlivosti [Two Sides of Tourist Attractiveness]. Geogr. Rozhl. 2015, 24, 8-9.

75. Goronzy, F. Die Inszenierung Des Paradieses: Eine Qualitative Inhaltsanalyse Von künstlichen Erlebniswelten; Diplomarbeiten Agentur diplom.de: Hamburg/Frankfurt, Germany, 2003.

76. Czech Television. Nejdeštivější červen za 60 let [The Rainiest June in 60 Years]. Available online: https:/ /www.ceskatelevize.cz/ ivysilani/1097181328-udalosti/220411000100708/obsah/777907-nejdestivejsi-cerven-za-60-let (accessed on 8 July 2020). 